\title{
A Comparative Study of 2-Dimensional Hydraulic Modeling Software, Case Study: Sorrento Valley, San Diego, California
}

\author{
Kian Bagheri ${ }^{1}$, Wynneth Requieron ${ }^{2}$ and Hassan Tavakol-Davani ${ }^{1}$ \\ ${ }^{1}$ San Diego State University, San Diego, California; ${ }^{2}$ Rick Engineering, San Diego, California.
}

\begin{abstract}
Sorrento West business park, a business campus for biotechnology and scientific research, is a flood prone hotspot in San Diego, California. Roselle Street and Dunhill Street experience flooding multiple times a year due to overtopping of adjacent channels, including Carroll Canyon Creek, Los Peñasquitos Creek and Flintkote Channel. A flood significantly affects the businesses and people of the area, trapping employees and customers inside businesses, forcing the shutdown of the Coaster service and access to the I-5 freeway, and causing hundreds of thousands of dollars in property damage. Previous one-dimensional hydraulic studies conducted on the flood capacity of these channels show that they only have capacity to contain the $5 \mathrm{y}$ storm event. This study incorporates two different two-dimensional hydraulic modeling techniques to supplement previous one-dimensional hydraulic studies. These two models were prepared with the United States Army Corps of Engineers Hydrological Engineering Center's River Analysis System (USACE HEC-RAS) and PCSWMM. In addition, a sensitivity analysis of the two two-dimensional models was performed to compare the response of the models to the research assumptions.
\end{abstract}

\section{Introduction}

Flooding is a global phenomenon that continues to threaten people, infrastructure and the environment in societies across the world. Climate change intensifies these effects because it increases the frequency of more intense storm events (Kalantari et al. 2014). Urbanization, which modifies the land surface by reducing vegetation, compacting soil and increasing the percentage of impervious surfaces, is also expected to increase these effects (Chen et al. 2017). These anticipated changes can lead to an amplified hydrological response. For example, as the development of impervious surfaces increases and natural vegetation decreases, infiltration and evapotranspiration decrease. This process results in higher peak discharges, even for short durations, from low intensity rainfall events (Chen et al. 2017). Likewise, as the frequency of intense storm events increases, peak runoff increases. The increase in peak runoff may result in channels or creeks that overtop and frequently flood adjacent roads, requiring costly repairs and, most importantly, threatening human lives (Kalantari et al. 2014). Thus there has been a need to assess and predict flood events and mitigate their impacts. As an example, the Sorrento West business park (Figure 1), in Sorrento Valley, continues to suffer from past flood events that have caused social and economic damage. Storm events force businesses to shut down early to ensure that employees and customers have time to leave the area before the streets become impassable (Figures 2-4). Flood mitigation measures are urgently needed for Sorrento Valley.

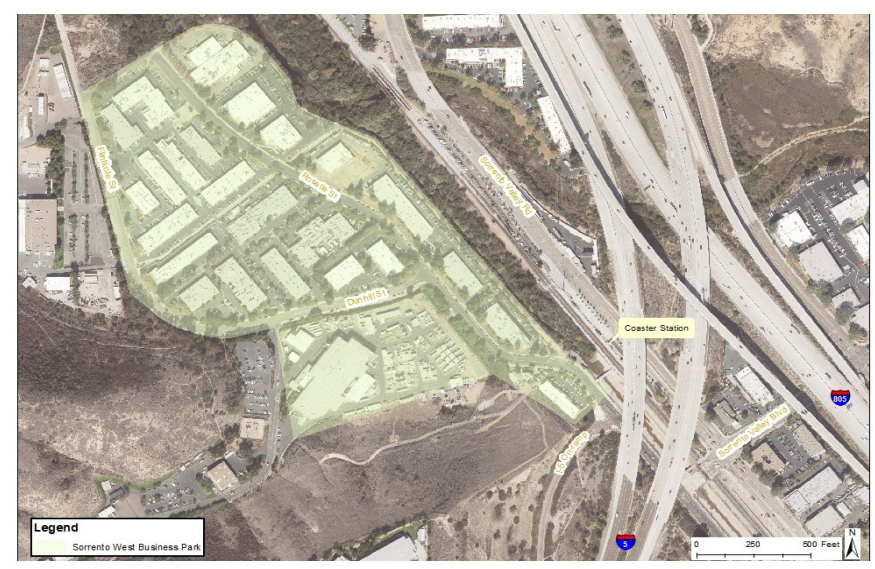

Figure 1 Map of Sorrento West business park.

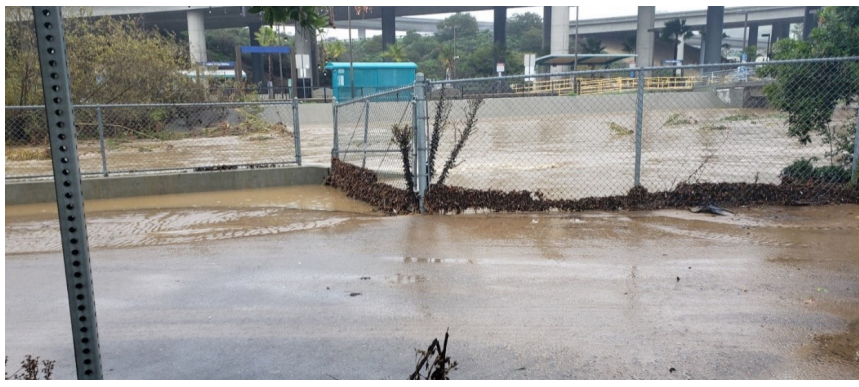

Figure 2 Carroll Canyon channel wedged in between the Coaster station and Roselle Street during the 2019-0214 storm event.

Bagheri, Kian, Wynneth Requieron and Hassan Tavakol-Davani. 2020. "A Comparative Study of 2-Dimensional Hydraulic Modeling Software, Case Study: Sorrento Valley, San Diego, California." Journal of Water Management Modeling 28: C471. doi: 10.14796/JWMM.C471.

(c) CHI 2020. www.chijournal.org ISSN 2292-6062. 


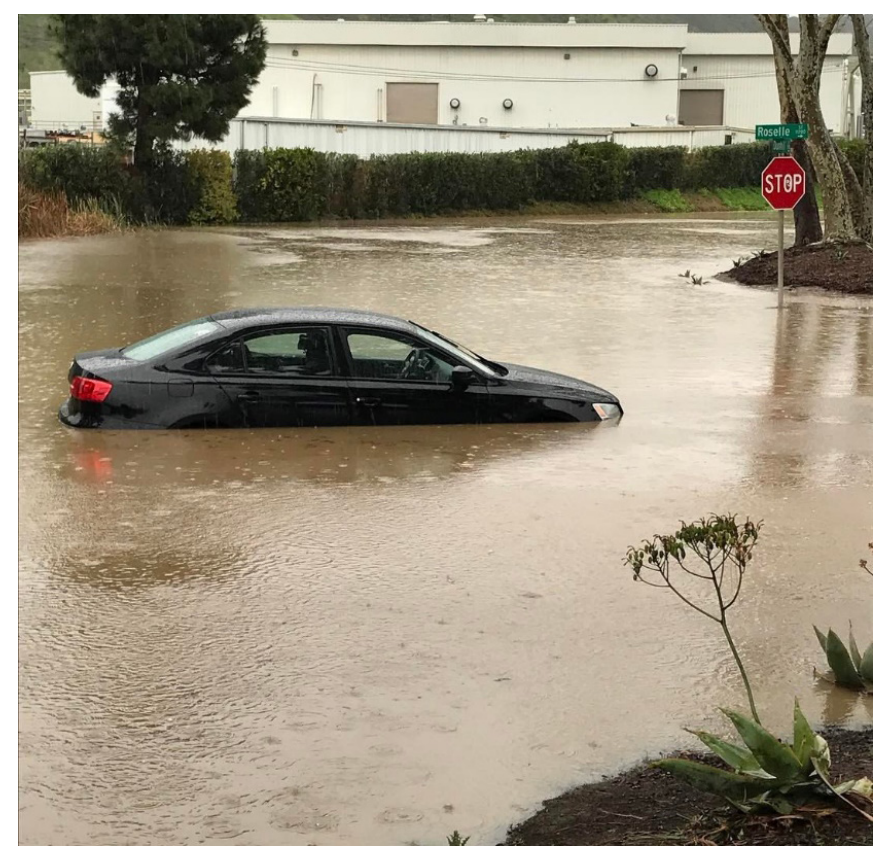

Figure 3 Flooding at the intersection of Roselle Street and Dunhill Street on 2017-02.

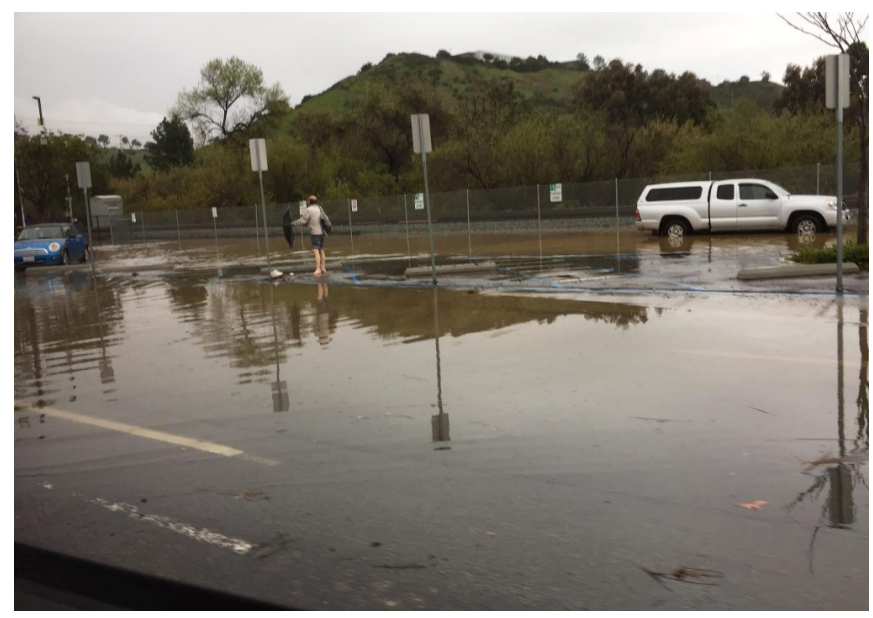

Figure 4 Flooding at the Coaster station parking lot on 2019-02-14.

Flood risk assessment and management are critical to detecting specific flood prone zones and reducing them in future flood events. Flood risk assessment can be done by analyzing past flood events based on onsite flood observation or remote sensing. However, such measures may be limited or not readily available, in which case flood risk assessment must be performed using numerical hydraulic modeling. Numerical modeling is a tool for evaluating multiple flood events and integrating various management strategies, and is thus especially useful for stakeholders to make informed decisions on how to manage the risk. There have been numerous studies that use numerical models to produce hazard maps for different management strategies (Moya Quiroga et al. 2016).
Before the availability of advanced technology and detailed terrain data, most hydraulic models only dealt with one-dimensional (1D) flow in the stream direction. This is a sufficient tool for modeling riverine and more confined channels where water typically does not overflow. Examples of 1D computer programs include HEC-RAS 1D, MIKE 11 and USEPA SWMM. With the advent of more advanced computers, two-dimensional (2D) hydrologic models are more widely available. In 2D analysis, the flow of water is analyzed in both the $x$ and the $y$ directions; the $z$ direction is neglected. Since the horizontal length scales are greater than the vertical length scale and pressure is assumed to be hydrostatic, vertical velocity and the vertical derivative terms in the Saint-Venant equations are ignored (USACE 2016). Although 2D models usually require longer computational time, they are more suitable for modeling flows that overtop channels and spread in different directions through streets, parking lots and other wide terrain (Jorge et al. 2009). Furthermore, with the availability of more advanced and continuous terrain data, 2D models can more accurately depict the lateral flow between a channel and its floodplain. Available commercial 2D models currently include HEC-RAS 2D, FLO-2D, PCSWMM and more. In order for stakeholders and decisionmakers to make good use of these models, the results should be reliable and robust. This report evaluates the use of HEC-RAS 2D for a flood prone business park in San Diego in the hope of promoting its widespread use for other San Diego channels.

\section{Study Area and Data}

\subsection{Study Area}

Sorrento West business park is located west of Sorrento Valley, a region of San Diego, California. Sorrento West business park is a crucial node of Sorrento Valley that includes access to the Coaster station and the I-5 freeway. When flooding occurs in the area, the floodwaters block exit routes. Figure 5 shows the extents of the HEC-RAS 2D model.

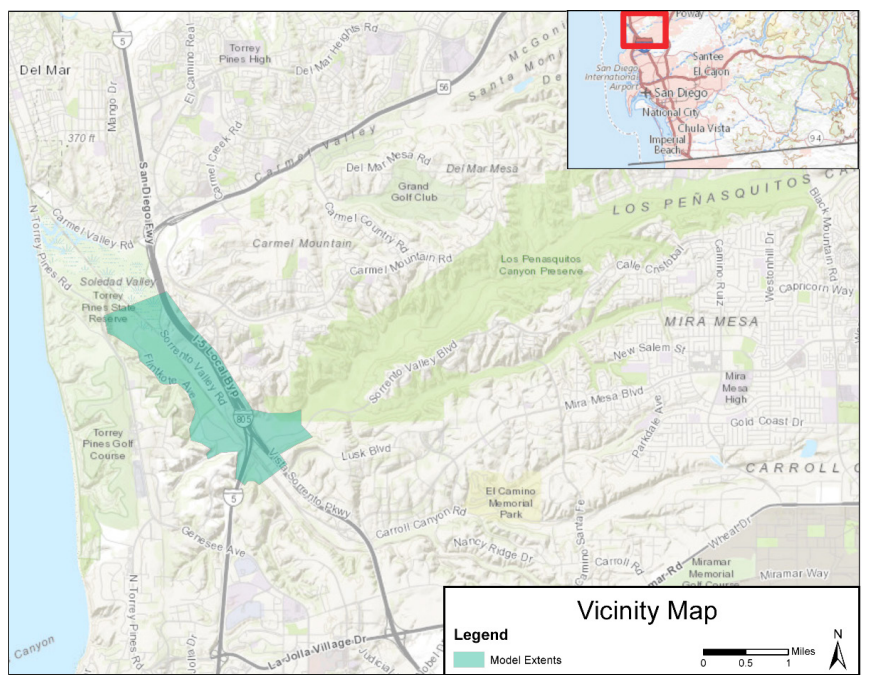

Figure 5 Study area map showing model extents. 
Sorrento West business park experiences flooding every year because it was developed in a floodplain. It was built in the late 1960s before the Army Corps of Engineers or the Federal Emergency Management Agency (FEMA) officially released a floodplain map of the area. Figure 6 shows the most recent flood plain maps released by FEMA.

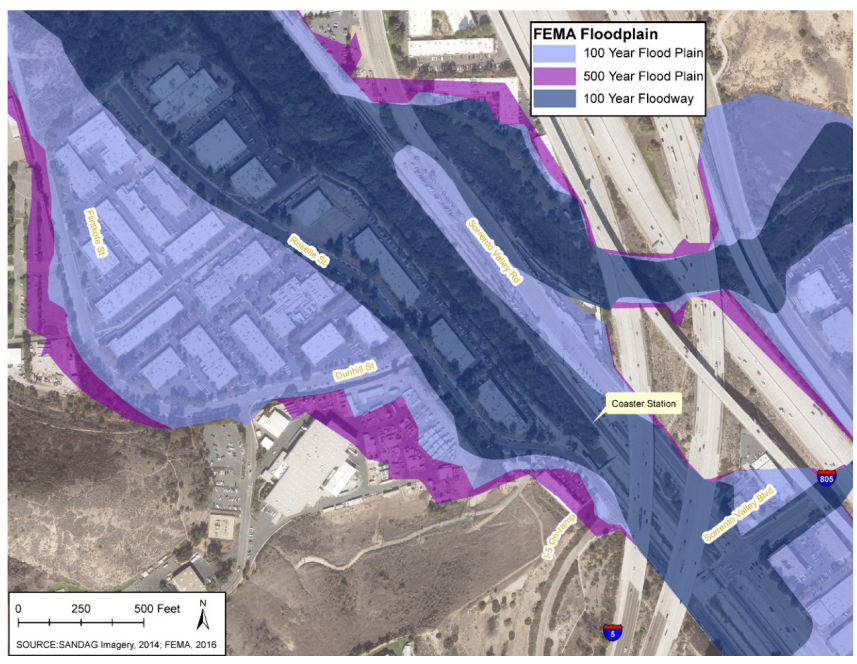

Figure 6 Floodplain map of study area for $100 \mathrm{y}$ and $500 \mathrm{y}$ floods and 100 y floodway.

In 1967, the Army Corps of Engineers addressed the issue that the channels in the area are inadequate for large flows (Kelly 1998). After the release of the Army Corps report, future developments had to be built on higher pad elevations to lift the buildings out of the flood plain; however, the streets around the area are still in the flood plain. For example, Roselle Street and Dunhill Street still experience flooding to this day, as shown in Figure 3 above.

Sorrento West business park is adjacent to the confluence of Carroll Creek and Los Peñasquitos Creek. The business park is located in the foothills and receives floodwaters from multiple reaches: Los Peñasquitos Creek to the east, Carroll Creek to the south and Flintkote Channel to the west. Each reach is supplied by its own subwatershed, Los Peñasquitos Canyon, Carroll Canyon or Flintkote, all of which have relatively steep topography. Los Peñasquitos Canyon is a highly urbanized watershed and spans near Poway in the east to Los Peñasquitos Lagoon in the west. Its drainage area is 36818 acres $\left(149 \mathrm{~km}^{2}\right)$. Carroll Canyon is an even more densely urbanized watershed, consisting mainly of industrialized areas, that begins at the Miramar Reservoir in the east and extends towards highway 805 in the west. Its drainage area is 11366 acres $\left(46 \mathrm{~km}^{2}\right)$. Flintkote watershed has a small drainage area of 61 acres that starts near Torrey Pines mesa in the west and flows downhill towards Sorrento West business park in the east. Figure 7 shows the contributing watersheds and their corresponding reaches.

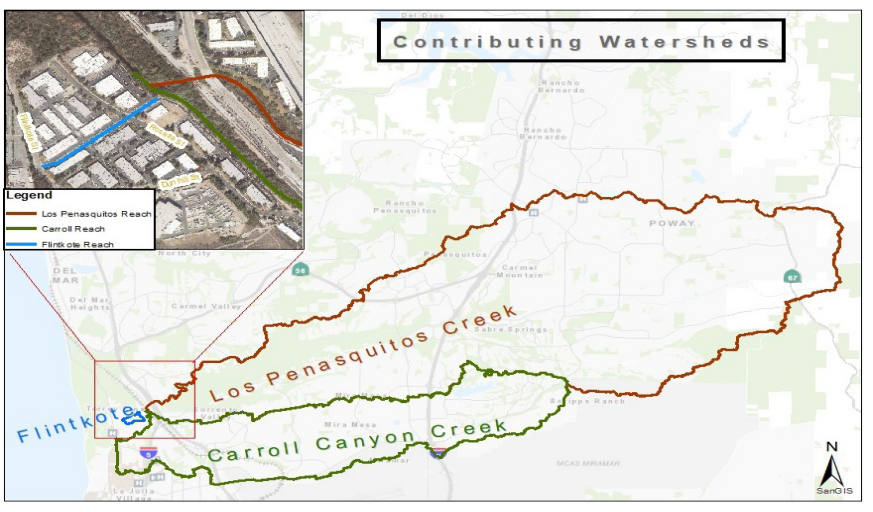

Figure 7 Contributing watersheds to Sorrento West business park study area.

\subsection{Data}

The two main types of input used for the 2D model in this study are geometric data that provide a physical description (i.e. elevation and Manning's roughness) of the study area, and hydrology data that provide information of flow discharge over time for the three reaches and the tidal stage at the downstream boundary condition near the Los Peñasquitos Lagoon. The geometric data used were in the form of a digital elevation model with the datum NAD83 (2011) from the San Diego Association of Governments (SANDAG) with a grid cell resolution of $2.5 \mathrm{ft} \times 2.5 \mathrm{ft}$ $(76.2 \mathrm{~cm} \times 72.6 \mathrm{~cm})$. A Manning's roughness map was created using ArcMap 6.1, where land cover was separated by polygons and associated with the appropriate roughness coefficient. Manning's $n$ values were generated from the City of San Diego's Drainage Design Manual using Table C-5 (City of San Diego 2017). Figure 8 shows the terrain data and roughness coefficients assigned for the study area.

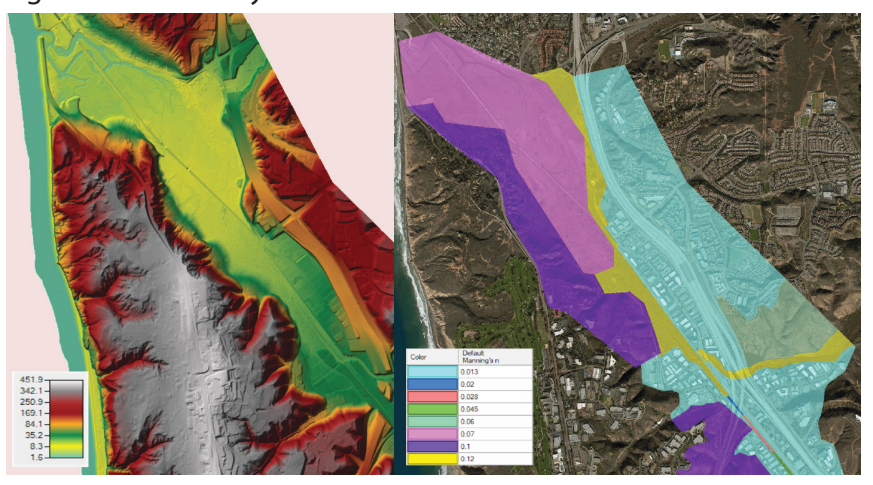

Figure 8 Terrain data (ft) with datum NAD83 (2011, left) and Manning's $n$ roughness (right).

The flow data at each reach was created using the Snyder unit hydrograph method and validated with the SCS triangular method. Characteristics of the watersheds (flow length, average slope) were calculated from the digital elevation model. Additionally, the curve number for each watershed was calculated by gathering land use and soils data from SANDAG and associating 
each land use type with the appropriate curve number (CN) using Table B-1 of the Drainage Design Manual (City of San Diego 2017). A weighted $\mathrm{CN}$ for each watershed was calculated by multiplying the $\mathrm{CN}$ value of each land type by its percentage area and summing the weighted $\mathrm{CN}$ values (i.e. weighted average). Lastly, the tidal influence at Los Peñasquitos Lagoon was accounted for in the data input. The tidal depth of $4.69 \mathrm{ft}$ ( $1.43 \mathrm{~m}$ ) was used as a boundary condition upstream of the lagoon (ESA 2016).

\section{Methodology}

\subsection{Flood Hydrographs}

The Snyder synthetic unit hydrograph (SUH) and Soil Conservation Service (SCS) triangular hydrograph methods were adopted to create discharge hydrographs at the three reaches, Los Peñasquitos Canyon, Carroll Creek and Flintkote. The discharge hydrographs were developed based on a $10 \mathrm{y}$ flood and $6 \mathrm{~h}$ rainfall.

\section{Snyder's Synthetic Unit Hydrograph (1938)}

Snyder's SUH method was developed from a study of watersheds in the Appalachian Highlands with basins ranging from $10 \mathrm{mi}^{2}$ to $10000 \mathrm{mi}^{2}$ ( $26 \mathrm{~km}^{2}$ to $25900 \mathrm{~km}^{2}$; Ramirez 2000). SUH relates watershed characteristics to three basic parameters of typical unit hydrographs, the lag time $t_{l}$ peak discharge $Q_{p}$ and base time $t_{b}$. These three parameters are used to describe the shape of the unit hydrograph:

$$
\begin{aligned}
& t_{l}=C_{t}\left(L \times L_{c}\right)^{0.3} \\
& Q_{p}=640 C_{p} A / t_{l} \\
& t_{b}=3+\frac{t_{l}}{8}
\end{aligned}
$$

where:

$t_{1}=$ lag time $(\mathrm{h})$,

$L=$ length of the main stream (mi),

$L_{c}=$ length of the main stream from the outflow to a point opposite the centroid of the watershed (mi),

$A=$ watershed area $\left(\mathrm{mi}^{2}\right)$,

$Q_{p}=$ peak discharge (cfs),

$t_{b}=$ base time,

$C_{t}=$ basin coefficient, which varies from 1.8 to 2.2 , and

$C_{p}=$ peaking coefficient, which varies from 0.4 to 0.8 (USACE 2000).

For the purposes of this study, coefficients $C_{t}$ and $C_{p}$ were assumed to be 1.4 and 0.7 . In addition to the three parameters, two characteristic points of the unit hydrographs were added. The widths of the unit hydrograph at $50 \%$ and $75 \%$ of $Q_{p}$ were defined using the following equations:

$$
W_{50}=830 / Q_{p}^{1.1}
$$

$$
W_{75}=470 / Q_{p}^{1.1}
$$

where:

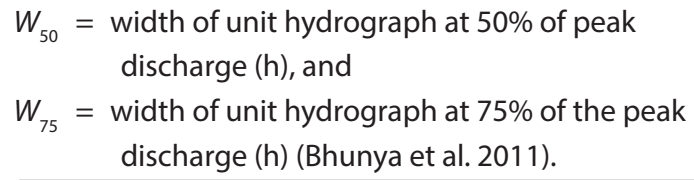

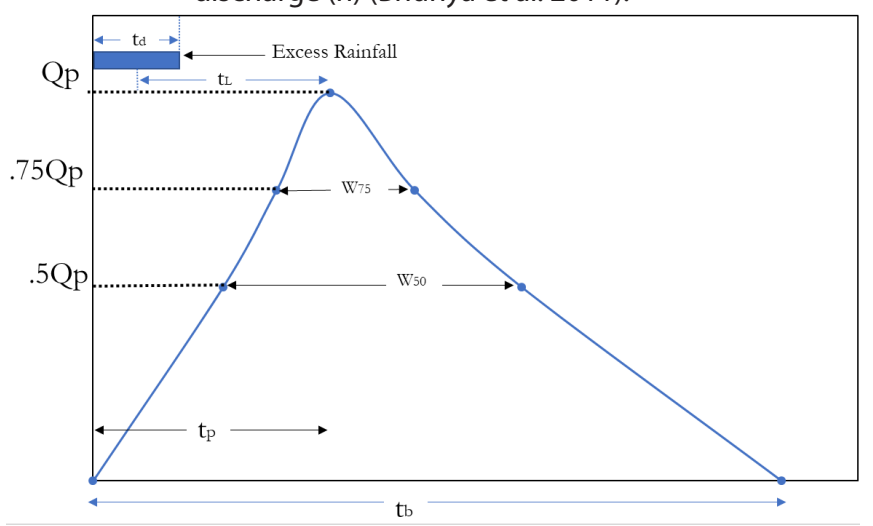

Figure 9 Shape of a typical Snyder unit hydrograph (Khidir and Al-Sha'ar 2017).

\section{SCS Triangular Method}

The Natural Resources Conservation Service, formerly known as the Soil Conservation Service, developed a hydrograph method that was derived from the analysis of numerous unit hydrographs from basins of different sizes and geographic locations. The triangular method assumes that $37.5 \%$ (or $3 / 8$ ) of the total runoff volume is attributed to the rising side of the hydrograph and the remaining $62.5 \%$ is attributed to the recession side. The following equations are used to define the shape of the triangular hydrograph.

$$
\begin{aligned}
T_{L} & =\left[\left(l^{0.8}\left(\frac{1000}{C N}-9\right)^{0.7}\right) / 1900 Y^{0.5}\right] \\
T_{p} & =\frac{\Delta D}{2}+T_{L} \\
Q_{p} & =\frac{484 A}{T_{p}} \\
T_{b} & =1.67 T_{p}
\end{aligned}
$$

where:

$$
\begin{aligned}
T_{L} & =\text { lag }(\mathrm{h}), \\
I & =\text { flow length }(\mathrm{ft}), \\
C N & =\text { curve number, } \\
Y & =\text { average watershed land slope }(\%), \\
T_{p} & =\text { time to peak }(\mathrm{h}), \\
D & =\text { duration of rainfall }(\mathrm{h}), \\
Q_{p} & =\text { peak discharge }(\mathrm{cfs}), \\
A & =\text { area }\left(\mathrm{mi}^{2}\right), \text { and } \\
T_{b} & =\text { time to base }(\mathrm{h}) .
\end{aligned}
$$




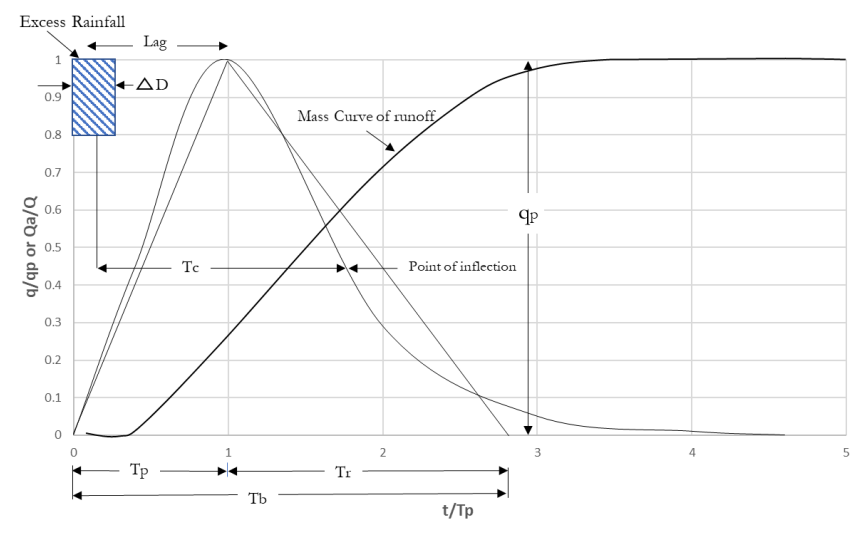

Figure 10 Shape of SCS triangular unit hydrograph (USDA 2004).

\subsection{Numerical Simulation: HEC-RAS}

The flood event was simulated using United States Army Corps of Engineer's HEC-RAS 2D version 5.0.6. The HEC-RAS 2D program can solve flows using either the Saint-Venant equations or the diffusion wave equations, which are respectively based on the principles of conservation of mass and conservation of momentum. The present study only considers the 2D diffusion wave option in simulating the flood event.

HEC-RAS 2D combines the conservation of mass and the diffusion wave form of the momentum equation to compute the water surface elevation at a point in time. The unsteady differential form of the conservation of mass equation, also known as the continuity equation, is (USACE 2016):

$$
\frac{\partial H}{\partial t}+\frac{\partial(u h)}{\partial x}+\frac{\partial(v h)}{\partial y}+q=0
$$

where:

$$
\begin{aligned}
t= & \text { time } \\
H= & \text { water surface elevation, } \\
h= & \text { water depth, } \\
q= & \text { a source or sink term, and } \\
u, v= & \text { the velocity components in the } x \text { and } y \\
& \text { directions. }
\end{aligned}
$$

The continuity equation can be rewritten in vector form, as:

$$
\frac{\partial H}{\partial t}+\nabla \cdot h V+q=0
$$

where:

$V(u, v)=$ velocity, and

$\nabla(\partial / \partial x, \partial / \partial y)=$ vector of the partial derivative.

The full momentum equations in the $x$ and $y$ directions are:

$$
\begin{aligned}
& \frac{\partial u}{\partial t}+u \frac{\partial u}{\partial x}+v \frac{\partial u}{\partial y}=-g \frac{\partial H}{\partial x}+v_{t}\left(\frac{\partial^{2} u}{\partial x^{2}}+\frac{\partial^{2} u}{\partial y^{2}}\right)-c_{f} u+f v \\
& \frac{\partial v}{\partial t}+u \frac{\partial v}{\partial x}+v \frac{\partial v}{\partial y}=-g \frac{\partial H}{\partial y}+v_{t}\left(\frac{\partial^{2} v}{\partial x^{2}}+\frac{\partial^{2} v}{\partial y^{2}}\right)-c_{f} v+f u
\end{aligned}
$$

where:

$$
\begin{aligned}
g & =\text { gravitational acceleration, } \\
v_{t} & =\text { horizontal eddy viscosity coefficient, } \\
c_{f} & =\text { bottom friction coefficient, and } \\
f & =\text { Coriolis parameter. }
\end{aligned}
$$

The vector form of the full momentum equation becomes:

$$
\frac{\partial v}{\partial t}+V \cdot \nabla V=-g \nabla H+v_{t} \nabla^{2} V-c_{f} V+f k \times V
$$

where:

$$
k=\text { unit vector in the vertical direction. }
$$

The terms of the equation, from left to right, represent unsteady acceleration, convective acceleration, barotropic pressure, eddy diffusion, bottom friction, and Coriolis effect. The diffusion wave form of the momentum equation disregards the unsteady, advection, turbulence and Coriolis terms, thus simplifying the equation to:

$$
-g \nabla H=c_{f} V
$$

In addition, HEC-RAS uses Manning's equation to represent bottom friction. The diffusion wave equation then turns to:

$$
-g \nabla H=\left(\frac{n^{2} g|V|}{R^{4 / 3}}\right) V
$$

where:

$$
\begin{aligned}
& n=\text { Manning's roughness coefficient, and } \\
& R=\text { hydraulic radius. }
\end{aligned}
$$

The velocity is determined by assuming that flow movement is driven by the balance between the barotropic pressure gradient and bottom friction.

$$
V=-\left((R(H))^{2 / 3} / n\right) \frac{(\nabla H)}{|\nabla H|^{1 / 2}}
$$

The diffusion wave is then substituted in to the continuity equation to derive a single equation model, the diffusion wave approximation, which is used to solve for $H$, the water surface elevation (WSE):

$$
\frac{\partial H}{\partial t}-\nabla \cdot \frac{(R(H))^{5 / 3}}{n|\nabla H|^{1 / 2}} \nabla H+q=0
$$

Although the program can solve for either the 2D Saint-Venant equations or the 2D diffusion wave equations, we opted to use the 2D diffusion wave equations for analysis. The diffusion wave method provides the same stable results as the Saint-Venant method but in a much shorter computation time. HEC-RAS 2D discretizes the study area, encompassing the rivers and adjacent floodplain areas, in a collection of individual cells called grid cells. These grid cells are polygons composed of 3 to 8 sides. Each grid cell contains elevation and roughness data to represent the terrain elevation and friction effects used to solve the diffusion wave equations. We used rectangular grid cells that are $20 \mathrm{ft} \times 20 \mathrm{ft}(6.1 \mathrm{~m} \times 6.1 \mathrm{~m})$ in size. This grid size was selected to optimize stability and efficiency of the model. Larger grid sizes generated unstable results, and smaller grid sizes took longer 
computation time. At each cell face, hydraulic properties (cross sectional area, wetted perimeter and hydraulic radius) are computed. Then WSE-volume relationships are computed for each cell and WSE-hydraulic properties relationships are computed for every cell face. The grids interface between the cell faces. The diffuse wave equations were solved with an iterative scheme (USACE 2016).

\subsection{Numerical Simulation: PCSWMM}

PCSWMM incorporates the 1D depth averaged momentum and continuity equations for homogenous fluids, which are solved along each component of a computational cell (CHI 2019). This model spans a network of junctions and open conduits, representing the study area hydrography, bathymetry or topography. The 2D software does not consider Coriolis force, wind shear forces or turbulent eddy viscosity. The form of the continuity equation used by PCSWMM is:

$$
\frac{\partial A}{\partial t}+\frac{\partial Q}{\partial x}=0
$$

where:

$$
\begin{aligned}
x & =\text { distance along the conduit }(\mathrm{m}), \\
t & =\text { time }(\mathrm{s}), \\
A & =\text { cross sectional area }\left(\mathrm{m}^{2}\right), \text { and } \\
Q & =\text { flow rate }\left(\mathrm{m}^{3} / \mathrm{s}\right)
\end{aligned}
$$

The form of the conservation of momentum equation used is:

$$
\frac{\partial Q}{\partial t}+\frac{\partial(Q / A)}{\partial x}+g A \frac{\partial H}{\partial x}+g A S_{f}+g A h_{L}=0
$$

where:

$$
\begin{aligned}
x= & \text { distance along the conduit }(\mathrm{m}), \\
t= & \text { time }(\mathrm{s}), \\
A= & \text { cross sectional area }\left(\mathrm{m}^{2}\right), \\
Q= & \text { flow rate }\left(\mathrm{m}^{3} / \mathrm{s}\right), \\
H= & \text { hydraulic head of water in the conduit }(\mathrm{m}), \\
S_{f}= & \text { friction slope }(\mathrm{m} / \mathrm{m}), \\
h_{L}= & \text { local energy loss per unit length of conduit } \\
& \quad(\mathrm{m} / \mathrm{m}), \text { and } \\
g= & \text { acceleration of gravity }\left(\mathrm{m} / \mathrm{s}^{2}\right) .
\end{aligned}
$$

These equations are solved by the finite difference method for solving differential equations, with successive approximations. PCSWMM 2D represents the $2 \mathrm{D}$ domain with a hexagonal or rectangular mesh for the overall study area and represents each cell with $2 \mathrm{D}$ nodes. The average bottom elevation within each cell is used as the invert elevation. Adjacent nodes relate to rectangular open channels or in some cases 2D conduits. A small surface area which is usually $0.1 \mathrm{~m}^{2}$ is provided for the nodes and then each cell has a conduit connected to the surface area of each cell in order to preserve continuity. The lengths and widths of conduits are adjusted based on a specific ratio that is dependent on the number of links that are connected to the node, which was determined empirically from tests to give expected wave speeds for a wide array of scenarios. Lastly, PCSWMM calculates the depth-averaged water velocity for each $2 \mathrm{D}$ cell through calculating the vector sum of the velocities associated with each that has flow leaving the $2 \mathrm{D}$ cells.

\subsection{Sensitivity Analysis}

Sensitivity analysis was undertaken to understand how changes in model inputs can affect model outputs, particularly the water surface elevation. The reasons for using sensitivity analysis are to identify factors that significantly affect the model output, to identify factors that need to be more accurate to improve confidence in the model results, and to evaluate the robustness of the model in response to possible variations in input factors (Hall et al. 2009). We used the one-at-a-time (OAT) sensitivity technique, in which one input factor is varied while the other inputs are kept at their nominal values. The Manning's roughness inputs and the grid size of the study area were varied separately to evaluate their effects on the resulting water surface elevation. The input factors were varied by $\pm 10 \%$ from baseline. This same process was repeated for the PCSWMM model, excluding the changes to grid size.

\section{Results and Discussion}

\subsection{Snyder SHU and SCS Triangle Hydrographs}

Figures 11 and 12 show the resulting Snyder's hydrograph and SCS triangle hydrograph for the Los Peñasquitos watershed. The hydrographs were scaled to exert a peak discharge of $3700 \mathrm{cfs}$ (105 m³/s); (FEMA 2012). The SCS hydrograph delayed the peak time by $1 \mathrm{~h}$ compared to the SHU hydrograph. However, it had a base time that was $5 \mathrm{~h}$ sooner than the SHU hydrograph. The shape of both hydrographs was generally the same; thus the results can be deemed reliable. The SHU hydrograph was input into the HEC-RAS 2D model.

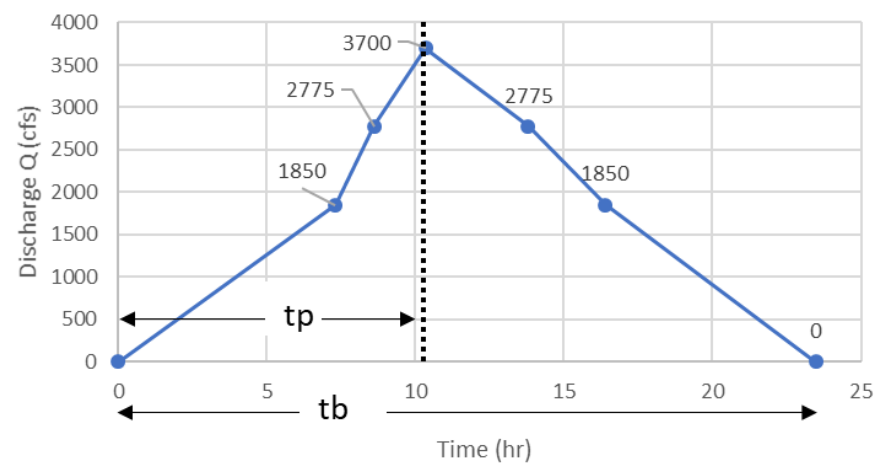

Figure 1110 y hydrograph for Los Peñasquitos Creek using Snyder's method. 


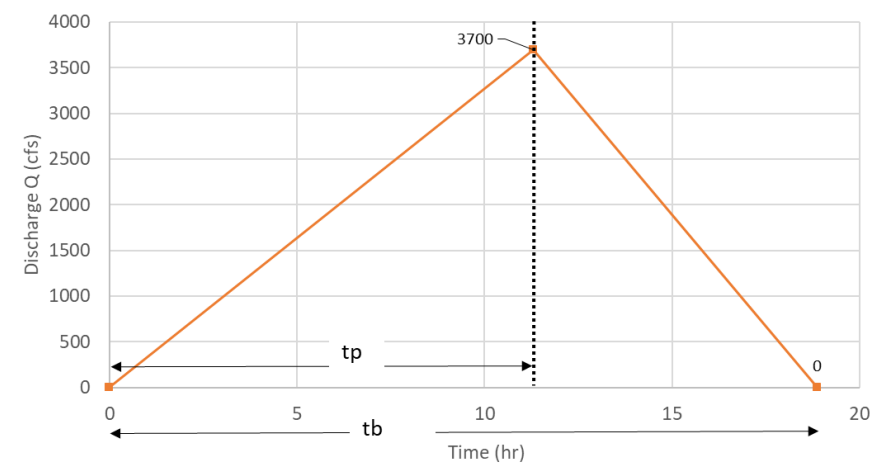

Figure 1210 y hydrograph for Los Peñasquitos Creek using SCS triangle method.

Figures 13 and 14 show the SHU and SCS hydrographs for the Carroll Canyon watershed. The hydrographs were scaled to exert a peak discharge of $1500 \mathrm{cfs}\left(42.5 \mathrm{~m}^{3} / \mathrm{s}\right)$; (FEMA 2012). Both hydrographs had similar peak times at $9 \mathrm{~h}$. The SCS hydrograph had a base time that was $4 \mathrm{~h}$ sooner than the SHU hydrograph. Each hydrograph's time to peak and time to base were fairly consistent. The Carroll Canyon 10 y SHU hydrograph was input into the HEC-RAS 2D model.

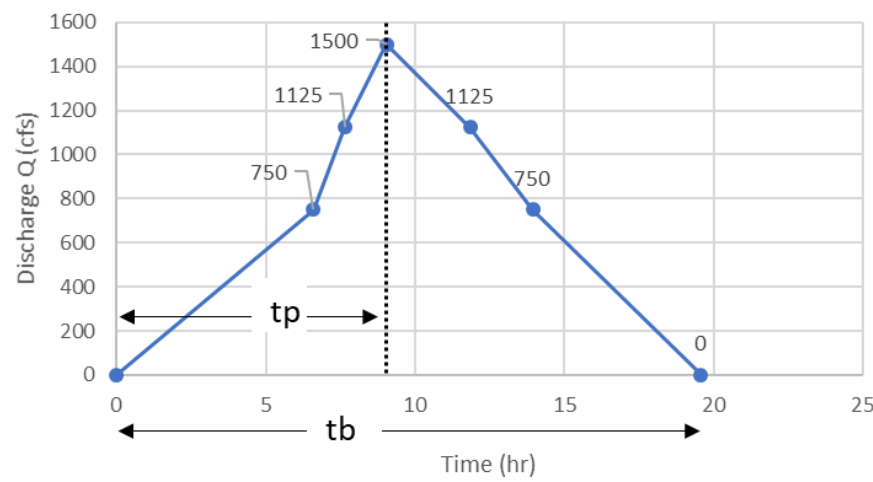

Figure 1310 y hydrograph for Carroll Canyon using Snyder's method.

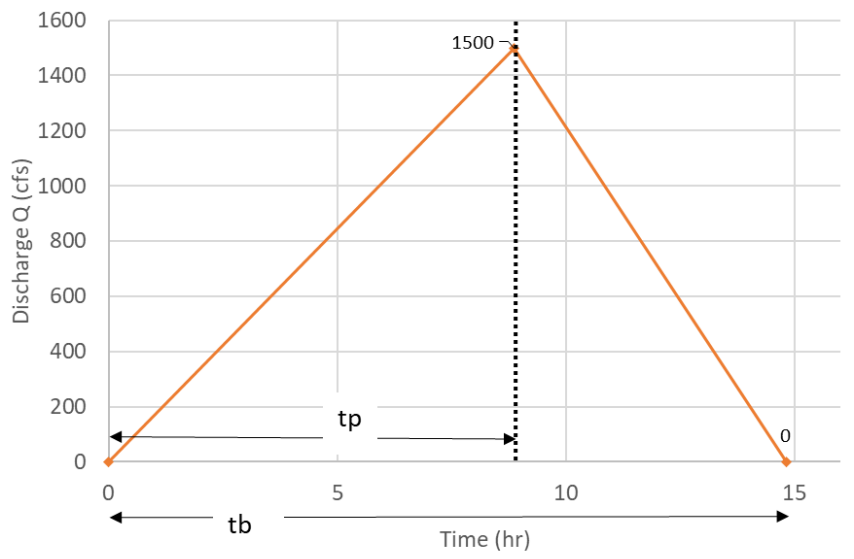

Figure 1410 y hydrograph for Carroll Canyon using SCS triangle method.
Figures 15 and 16 show the resulting SHU and SCS hydrographs for the Flintkote Channel watershed. The hydrographs were scaled to exert a peak discharge of $98 \mathrm{cfs}\left(2.8 \mathrm{~m}^{3} / \mathrm{s}\right.$; URS Corporation 2013). The SCS hydrograph peaked and receded approximately $1 \mathrm{~h}$ earlier than the SHU hydrograph. The time to peak and time to base are fairly consistent between the hydrographs. The Flinkote Channel 10 y SHU hydrograph was input into the HEC-RAS 2D model.

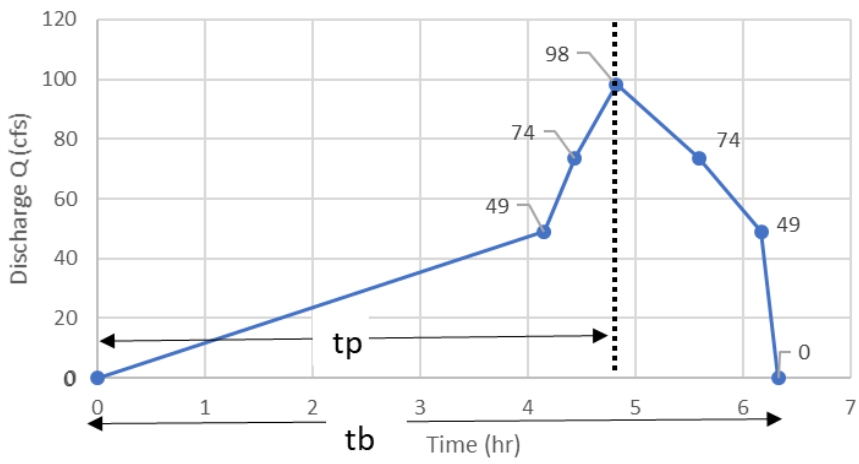

Figure $1510 \mathrm{y}$ hydrograph for Flintkote Channel using Snyder's method.

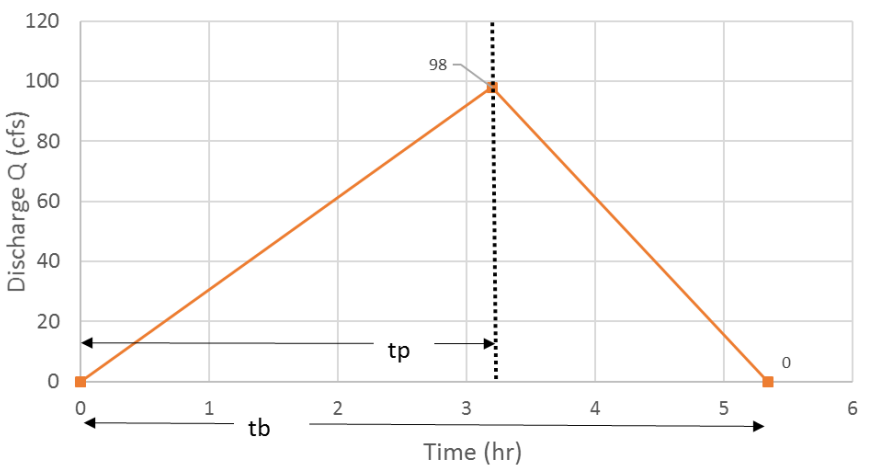

Figure $1610 \mathrm{y}$ hydrograph for Flintkote using SCS triangle method.

Overall, Los Peñasquitos displays the largest time-to-peak and peak discharge. Results for each watershed also show a steep increase in discharge once the watershed has reached $50 \%$ of its discharge for the flood in the watershed.

\subsection{HEC-RAS 2D 10 y flood based on existing conditions}

Figure 17 shows the HEC-RAS 2D results of the $10 \mathrm{y}$ flood event based on the existing conditions of the Sorrento Valley site. The results show flooding on the street between Los Peñasquitos Creek and Carroll Canyon Creek, with water at approximately $2.5 \mathrm{ft}(76 \mathrm{~cm})$ depth. Additionally, both Roselle Street and Dunhill Street become flooded, with water at approximately $1.84 \mathrm{ft}$ $(56 \mathrm{~cm})$ depth, due to overflows from Carroll Canyon Creek and Flintkote Channel. Carroll Canyon Creek overtops at the Coaster station, where flows spread northwest into Roselle Street and the adjacent parking lots of the business park. Flintkote Channel 
overtops, especially at Roselle Street intersection where three $4 \mathrm{ft} \times 2 \mathrm{ft}(122 \mathrm{~cm} \times 61 \mathrm{~cm})$ box culverts are located, and flows spread north into adjacent parking lots. The resulting inundation map shows significant flooding at Sorrento West business park. These results are corroborated by past flood events that have been observed and documented as shown in Figures 2 and 3 above.

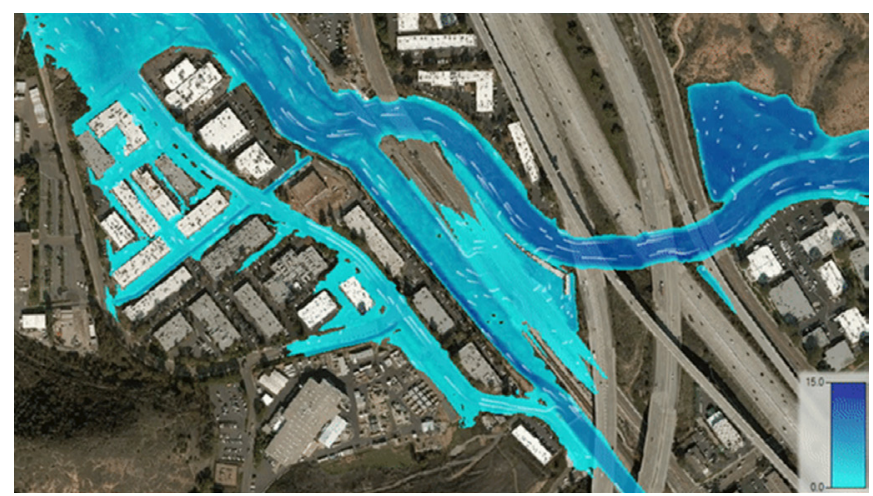

Figure 17 HEC-RAS 2D 10 y flood event based on existing conditions.

\subsection{PCSWMM 2D 10 y flood based on existing conditions}

Figure 18 shows the PCSWMM results of the $10 \mathrm{y}$ flood event based on the existing conditions and SCA hydrographs for Los Peñasquitos Creek and Carroll Canyon Creek. The results show that there will be flooding on the street between these two creeks, at an average depth of $2.82 \mathrm{ft}(86 \mathrm{~cm})$. The flooding at Roselle Street and Dunhill Street intersection is predicted at an average of $1.56 \mathrm{ft}(47.5 \mathrm{~cm})$. The results are similar to those of the HEC-RAS 2D model.

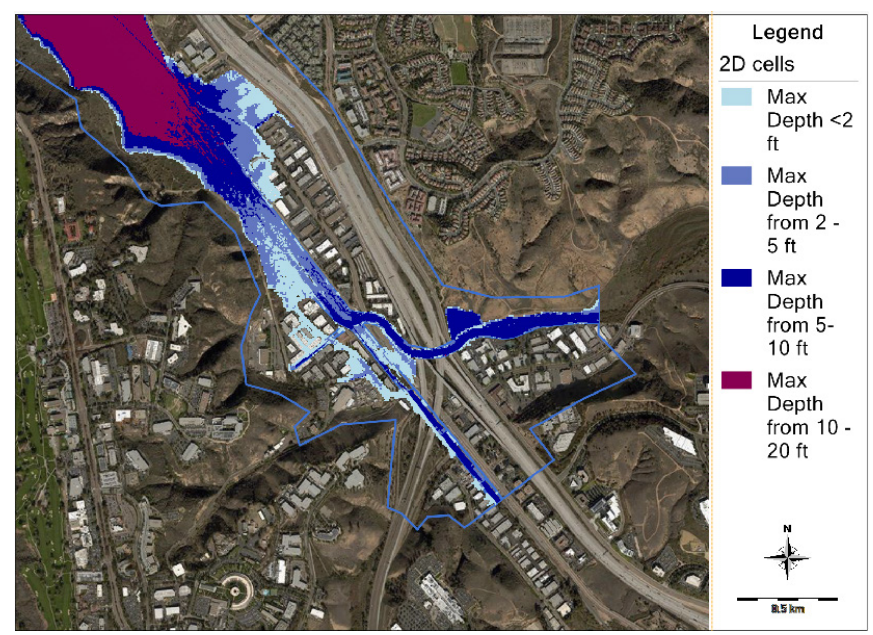

Figure 18 PCSWMM 10 y flood event based on existing conditions.

Although flooding did not surround the Sorrento West business park, the PCSWMM model shows that the critical streets that are used to exit the business park become excessively flooded. The PCSWMM simulation shows that the flooding mainly results from the flow being diverted from Carroll Creek Canyon and up Roselle Street, where it continues to spread across Dunhill Street and almost the entire business park. A closer view of the flooding is shown in Figure 19.

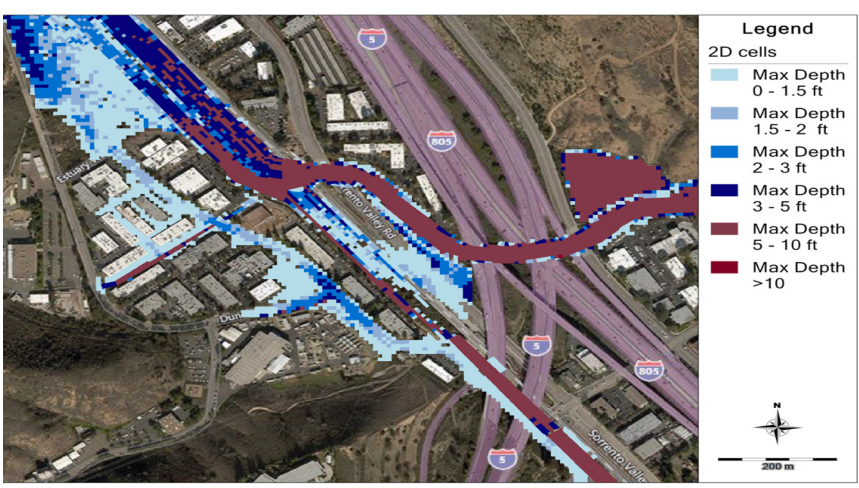

Figure 19 PCSWMM 10 y flood event closer look.

\subsection{HEC-RAS 2D 10 y proposed mitigation con- ditions}

In the proposed measure 1 conditions, the Manning's roughness coefficients for the earthen channels at Los Peñasquitos Creek and Carroll Canyon Creek were reduced to $n=0.065$ (originally $n=0.12$ ), assuming that sediment and vegetation buildup in the channel will be removed and native vegetation will be restored. Manning's coefficients for the channel at Carroll Canyon Creek were reduced to $n=0.016$ (see Figure 20 for further details). The results still show flooding on the streets of the business park. However, flooding on the parking lots has been considerably reduced (Figures 21 and 22).

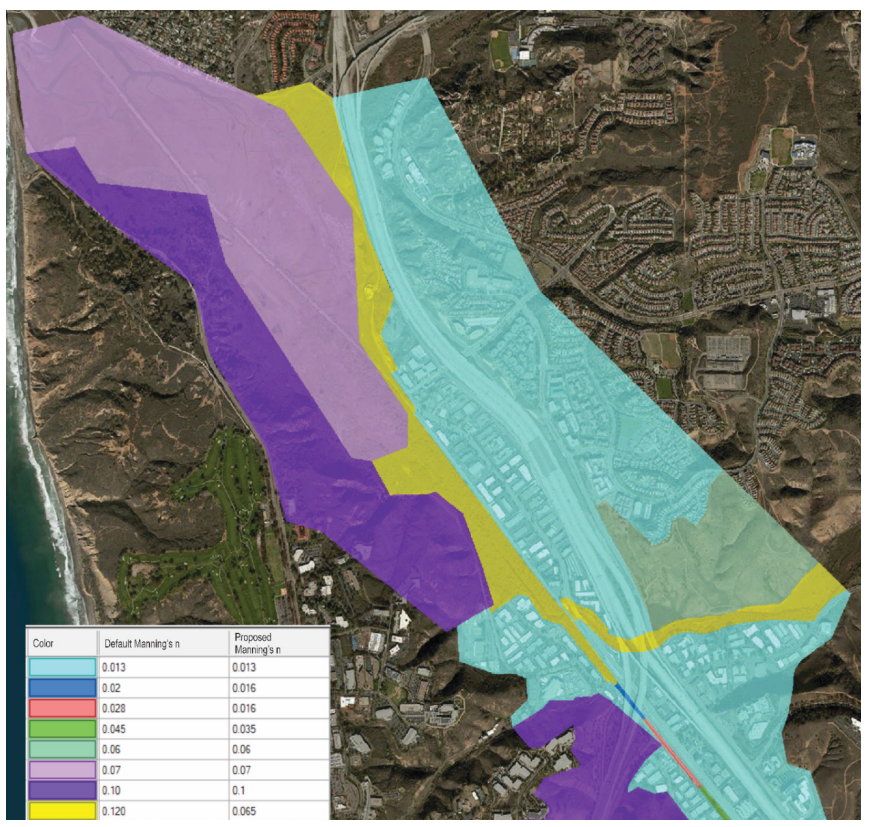

Figure 20 Manning's $n$ layer for proposed measures 1 and 2. 


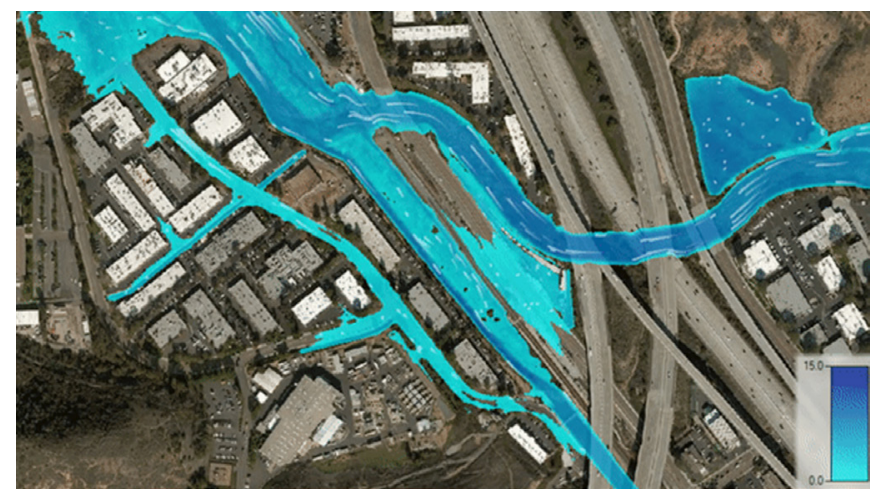

Figure 21 HEC-RAS $10 \mathrm{y}$ flood event based on proposed measure 1 .

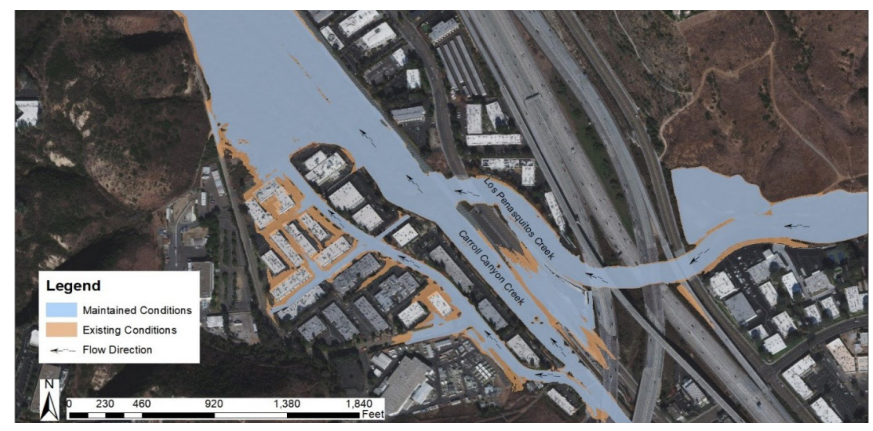

Figure 22 HEC-RAS flood extents for the $10 \mathrm{y}$ flood: existing vs proposed measure 1 .

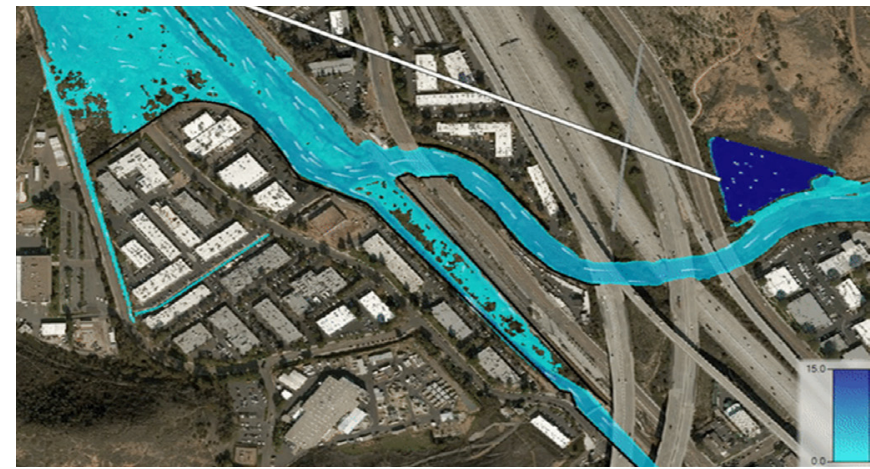

Figure 23 HEC-RAS $10 \mathrm{y}$ flood event based on proposed measure 2 .

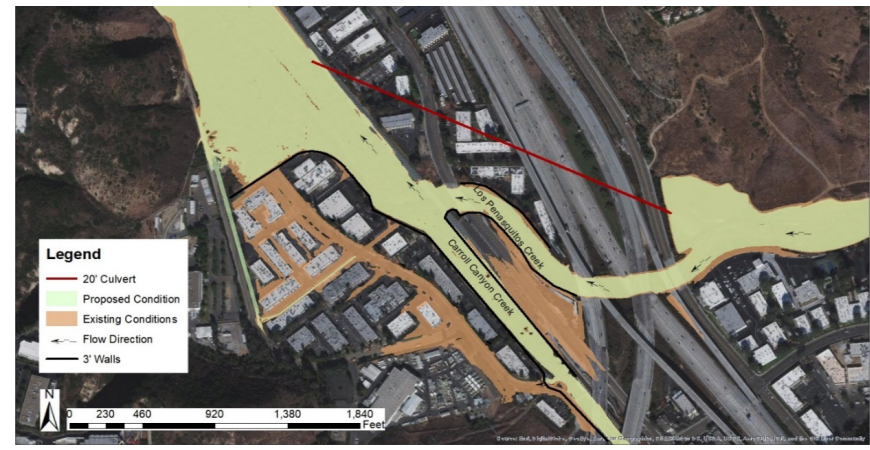

Figure 24 HEC-RAS flood extents for the $10 \mathrm{y}$ flood: existing vs proposed measure 2 .

\subsection{Sensitivity Analysis Results}

The location selected for the sensitivity analysis was the intersection of Roselle Street and Dunhill Street, which is shown by the green arrow in Figure 25. The results show that varying Manning's roughness coefficient by increments of $10 \%$ will cause a direct change in the water surface elevation by $0.52 \%$, whereas varying the cell size causes negligible change in the water surface elevation (.02\%). The cell size mostly dictates the computation time: the finer the cell size the longer the computation time of the model. In this study, the computation time varied from $8 \mathrm{~min}$ for the $30 \mathrm{ft} \times 30 \mathrm{ft}(9.1 \mathrm{~m} \times 9.1 \mathrm{~m})$ grid size to $90 \mathrm{~min}$ for the $10 \mathrm{ft} \times 10 \mathrm{ft}(3 \mathrm{~m} \times 3 \mathrm{~m})$ grid size. We used a Windows machine with an Intel i7-8700 CPU and 16 GB RAM. Figure 26 shows the result for the sensitivity analysis portion of the study relating to the HEC-RAS model.

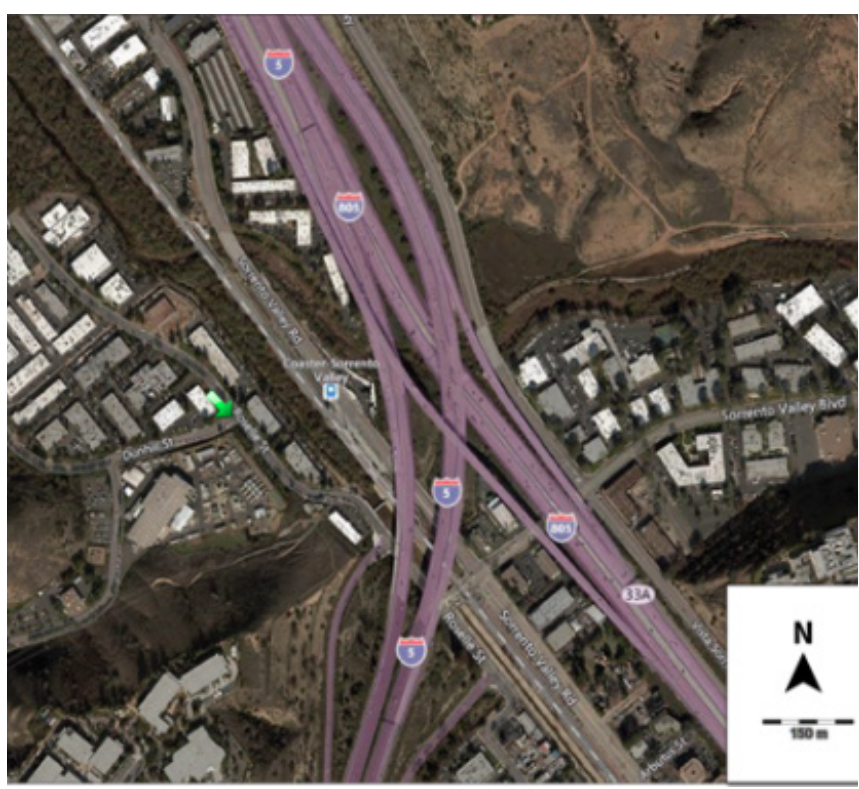

Figure 25 Location selected to conduct sensitivity analysis.

Because there were negligible changes in water surface elevation with changes in cell size, the comparison with PCSWMM was only concerned with changes in Manning's roughness. The sensitivity analysis was completed in the same manner using increments of $10 \%$ in the roughness values. Figure 27 displays the results of the OAT sensitivity analysis. Figures 26 and 27 show that the slope of OAT for HEC-RAS is around 3 times greater than that of PCSWMM, meaning that HEC-RAS is more sensitive to changes in the roughness values. This suggests additional considerations for picking the right roughness values when working with HEC-RAS. 


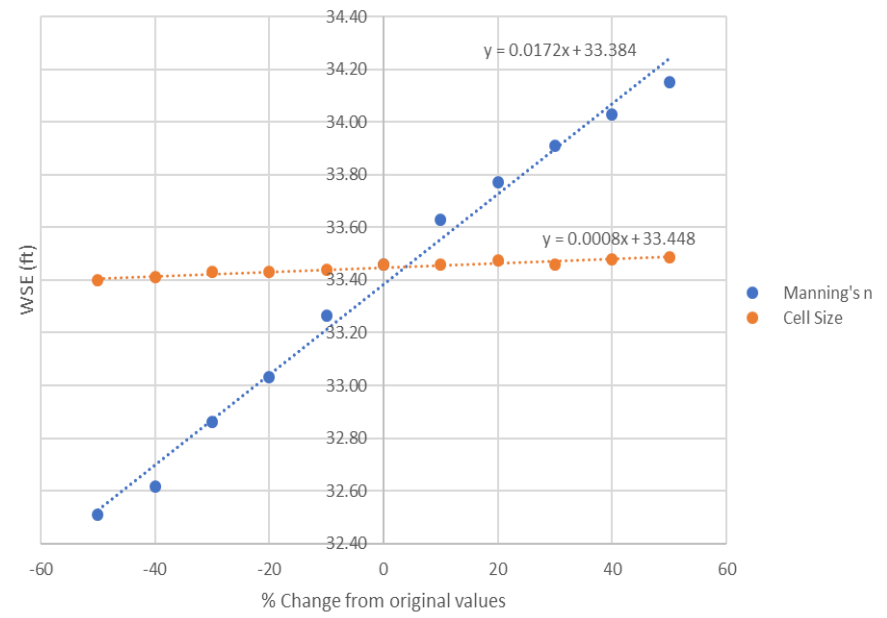

Figure 26 OAT sensitivity analysis graph for the HEC-RAS model.

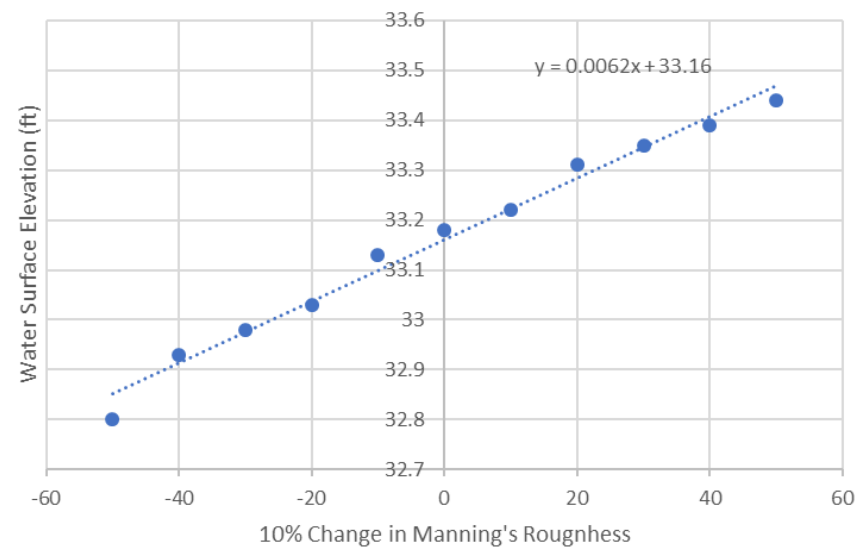

Figure 27 OAT sensitivity analysis graph for PCSWMM.

\section{Conclusions}

A 10 y flood event at the Sorrento West business park was simulated using the 2D capabilities of the HEC-RAS program. In creating the 2D model for the site, the user found that optimum performance can be achieved at a computation grid size of $20 \mathrm{ft} \times 20 \mathrm{ft}(6.1 \mathrm{~m} \times 6.1 \mathrm{~m})$, when the results show proper convergence of the calculations and a computation time that was not excessive.

The study showed that all three channels modeled (Los Peñasquitos, Carroll Canyon, and Flintkote) would overflow in the $10 \mathrm{y}$ flood event. As a result, adjacent roads, such as Roselle Street and Dunhill Street, would become flooded. Simulating the $10 \mathrm{y}$ flood event for existing conditions helped us to assess and manage the flood. Flooding in the streets was from two sources: overtopping of the Flintkote channel and overtopping of the Carroll Canyon channel at the Coaster station. After assessing the two sources, we found a possible solution to control the flooding. The flood can be controlled by:
1. Constructing a new trapezoidal channel perpendicular to the original Flintkote channel to divert flows behind the business park rather than through it;

2. Adding a $20 \mathrm{ft}(6.1 \mathrm{~m})$ culvert to divert a portion of the flow from Los Peñasquitos past the business park;

3. Removing vegetation and debris from all three reaches to reduce the Manning's roughness coefficient; and

4. Adding $3 \mathrm{ft}(91 \mathrm{~cm})$ walls around the business park.

This study also extended the results from the HEC-RAS 2D model, comparing them with the results from a PCSWMM model. The results showed similar flooding in both models, which increases confidence in the reliability of these models. The sensitivity analysis shows that there is a greater reaction to change in the Manning's roughness values with the HEC-RAS 2D model compared to PCSWMM.

Additionally, we analyzed the sensitivity of the resulting water surface elevation against two inputs, Manning's roughness coefficient and computational cell size. The sensitivity analysis showed that water surface elevation is significantly more dependent on Manning's roughness coefficient than the computational cell size.

Both the HEC-RAS 2D program and the PCSWMM program were useful tools for understanding flood events and analyzing possible management strategies. The study shows their applicability in a flood-prone area in San Diego.

\section{Acknowledgments}

The authors value and appreciate PCSWMM and SURP (Summer Undergraduate Research Program at San Diego State University) for their research grant and support resources that made this extension study possible.

\section{References}

Bhunya, P. K., S. N. Panda and M. K. Goel. 2011. "Synthetic Unit Hydrograph Methods: A Critical Review." Open Hydrology Journal 5:1-8.

Chen, J. L., M. G. Theller, B. Engel and J. Harbor. 2017. “Urbanization Impacts on Surface Runoff of the Contiguous United States." Journal of Environmental Management 187:470-81.

CHI. 2019. PCSWMM User Manual. Guelph: Computational Hydraulics International, https://www.chiwater.com

City of San Diego. 2017. Drainage Design Manual, Transportation and Storm Water Design Manuals. San Diego, CA: City of San Diego.

ESA (Environmental Science Associates). 2016. Los Penasquitos Lagoon Enhancement Plan-DRAFT. Torrey Pines, CA: Environmental Science Associates. 
FEMA (Federal Emergency Management Agency). 2012. Flood Insurance Study, San Diego County, California. Revised, May 16, 2012. Washington, DC: Federal Emergency Management Agency.

Hall, J. W., S. A. Boyce, Y. Wang, R. J. Dawson, S. Tarantola and A. Saltelli. 2009. "Sensitivity Analysis for Hydraulic Models." Journal of Hydraulic Engineering 10.1061/(ASCE)HY.1943-7900.0000098.

Jorge, L., A. S. Chen, S. Djordjević and D. A. Savić. 2009. “Comparison of 1D/1D and 1D/2D Coupled (Sewer/Surface) Hydraulic Models for Urban Flood Simulation." Journal of Hydraulic Engineering. 10.1061/(ASCE)HY.1943-7900.0000037.

Kalantari, Z., A. Briel, S.W. Lyon, B. Olofsson and L. Folkeson (2014). "On the Utilization of Hydrological Modelling for Road Drainage Design under Climate and Land Use Change." Science of the Total Environment, 475:97-103

Kelly, M. 1998. Flooding: Brought to you by the City of San Diego. A Telling History of a North County Watershed. San Diego, CA: San Diego Earth Times. <https://www.sdearthtimes.com/et0298/et0298s1.html> (Jan. 10, 2019).

Khidir, K. M. and M. T. Al-Sha'ar. 2017. “Estimating Storm Direct Runoff Using Synthetic Unit Hydrograph Methods by (WMS) Model." Journal of University of Duhok 20 (1): 727-35.
Moya Quiroga, V., S. Kure, K. Udo and A. Mano. 2016. “Application of 2D Numerical Simulation for the Analysis of the February 2014 Bolivian Amazonia Flood: Application of the New HEC-RAS Version 5." Ribagua 3 (1): 25-33.

Ramirez, J. A. 2000. Prediction and Modelling of Flood Hydrology and Hydraulics. Cambridge: Cambridge University Press.

URS Corporation. 2013. Individual Hydrologic and Hydraulic Assessment Report for Sorrento Creek - Flintkote, Soledad, and Los Penasquitos Channel. San Diego, CA: URS Corporation.

USACE (U.S. Army Corps of Engineers). 2000. Hydrologic Modeling System HEC-HMS-Technical Reference Manual. Davis, CA: U.S. Army Corps of Engineers Hydrologic Engineering Center, HEC. CPD74B.

USACE (U.S. Army Corps of Engineers). 2016. HEC-RAS River Analysis System Version 5.0 - Hydraulic Reference Manual. Davis, CA: U.S. Army Corps of Engineers Hydrologic Engineering Center, HEC. CPD-69.

USDA (U.S. Dept. of Agriculture). 2004. "Hydrographs." In National Engineering Handbook, ch.16, part 630. Washington, DC: U.S. Dept. of Agriculture Natural Resource Conservation Service. 